\title{
Determination of the trace metals in Bottled Water That Available in Erbil City, Iraq
}

\author{
*Janan Jabbar Toma and *Muhammad Aziz Othman \\ *Department of Environmental Sciences, College of Sciences. University of \\ Salahaddin.Hawler.Kurdistan region of Iraq.
}

Rec. 31 May, 2011 Accpt. 21 Jun, 2011

\begin{abstract}
Trace Metal composition of the Bottled water that available in Erbil city was assessed during January to April-2010 from different shops of the city. About ten bottled water samples were analyzed using Atomic Absorption Spectrophotometer for their Aluminum, Cadmium, Lead, Iron, Copper and Manganese content and their levels compared with World Health Organization specified maximum contaminant level. According to the WHO, the Maximum Contaminant Level (MCL) for Aluminum, Cadmium, Lead, Iron, Copper and Manganese are $0.2,0.003,0.01,1,2$ and $0.5 \mathrm{mg} / \mathrm{L}$ respectively. From the results obtained, none of the samples analyzed contained Aluminium in concentrations above the MCL, however, the metal was found to be present in $50 \%$ of the samples analyzed. Over $30 \%$ of the samples had Cadmium concentrations above the MCL. Almost $75 \%$ of the samples had detectable level of Lead while $40 \%$ of the sample had Lead concentration above the MCL. The results demonstrated that all of samples Iron, Copper and Manganese concentrations have been shown below MCL according to WHO. The analysis performed by Atomic Absorption Spectrophotometer, indicated that mostly the trace element were below the WHO guideline, except $30 \%$ and $40 \%$ of the samples had Cadmium and Lead concentrations above the MCL respectively.
\end{abstract}

Key words: Bottled water, Trace element, maximum contamination level

\section{Introduction:-}

Water is one of the essentials that supports all forms of plant and animal life (Vanloon and Duffy, 2005). and it is generally obtained from two principal natural sources; Surface water such as fresh water lakes, rivers, streams, etc. and Ground water such as borehole water and well water (McMurry and Fay, 2004; Mendie, 2005). Water has unique chemical properties due to its polarity and hydrogen bonds which means it is able to dissolve, absorb, adsorb or suspend many different compounds (WHO, 2007). thus, in nature, water is not pure as it acquires contaminants from its surrounding and those arising from humans and animals as well as other biological activities (Mendie, 2005). One of the most important environmental issues today is ground water contamination (Vodela et al., 1997) and between the wide diversity of contaminants affecting water resources, trace metals receive particular concern considering their strong toxicity even at low concentrations (Marcovecchio et al., 2007). Drinking water of good quality is essential for human health and development. Pollutants such as pesticides, fertilizers, bacteria, toxic metals and other potentially harmful - not yet identified - environmental contaminants may deteriorate the quality of drinking water in many regions of the world. With growing concern about the quality of municipal water, e.g. $\mathrm{Pb}$ and $\mathrm{Cu}$ contamination through the plumbing system (Zietz et al., 2001, 2003).

Bottled waters are becoming increasingly popular worldwide. Italy ranks as the country with the greatest annual production $(10$ billion L/year $)$ and consumption (151 L/per capita/year) (Versari et al., 2002). While tap water intended for human consumption is controlled regularly for an extensive array of potential contaminants by certified authorities, bottled waters undergo less comprehensive testing, and less frequently.

Moreover, the legal guidelines established to regulate the quality of tap water generally do not apply to bottled waters. The potential risks from exposure to potentially harmful contaminants from

* Corresponding author:
Dr. Janan Jabbar Toma
$凶$ janan_toma@yahoo.com


drinking bottled water, therefore, are rather difficult to assess.

Surveys have indicated that consumers are turning to bottled water as a healthy alternative to soft drinks or because they are concerned about the safety or taste of their drinking water (Dorothy, S and Nicholas, D, 2005). Bottled water comes from a variety of sources, like spring and mineral water are drawn from underground water sources such as a bore holes or spring, they differ according to their composition and content in mineral. Other bottled water can be either water from springs and wells or drinking water from the distribution system (Warburton and Austin, 2000).

In addition to the uncertain chemical composition of natural spring waters from diverse geological terrains, recent studies revealed that most bottled waters are contaminated with either antimony $(\mathrm{Sb})$ or lead $(\mathrm{Pb})$ leaching from polyethylene terephthalate (PET) and glass bottles, respectively (Shotyk et al., 2006).

With the growing awareness of the environmental impacts of water bottling and transportation, reusable water bottles are becoming increasingly popular. One of the more popular brands in this category is aluminium but with a proprietary, non-toxic liner. A second type of popular bottle is simply made of stainless steel. We know of no published studies of trace metal contamination as a result of leaching from such containers (Michael and William, 2009).

Trace element can cause serious health effects with varied symptoms depending on the nature and quantity of the metal ingested (Adepoju-Bello and Alabi, 2005). They produce their toxicity by forming complexes with proteins, in which carboxylic acid ($\mathrm{COOH})$, amine $(-\mathrm{NH} 2)$, and thiol $(-\mathrm{SH})$ groups are involved. These modified biological molecules lose their ability to function properly and result in the malfunction or death of the cells. When metals bind to these groups, they inactivate important enzyme systems or affect protein structure, which is linked to the catalytic properties of enzymes. This type of toxin may also cause the formation of radicals which are dangerous chemicals that cause the oxidation of biological molecules.
The most common trace element that humans are exposed to is Aluminium, Cadmium, Lead and Manganese. Aluminium has been associated with Alzheimer's and Parkinson's disease, senility and prehensile dementia. Arsenic exposure can cause among other illness or symptoms cancer, abdominal pain and skin lesions. Cadmium exposure produces kidney damage and hypertension. Lead is a commutative poison and a possible human carcinogen (Bakare-Odunola, 2005). There is thus the need to assess the quality of ground water sources.

The World Health Organization has specified Maximum Contaminant Level for the presence of trace element in water. The aim of this study is to assess the quality of bottled water sources in Hawler city, with the aid of Atomic Absorption Spectrophotometer the presence and concentration of six trace elements (Aluminium, Cadmium, Copper, Iron, Lead and Manganese) were determined and the results compared to the maximum contaminant level specified by the World Health Organization.

\section{Materials and Methods:}

Ten bottled water samples were collected from different shops in Erbil city during January to April-2010. To ensure the removal of organic impurities from the samples and thus prevent interference in analysis, the samples were digested with concentrated nitric acid. $10 \mathrm{ml}$ of nitric acid was added to $50 \mathrm{ml}$ of water in a $250 \mathrm{ml}$ conical flask. The mixture was evaporated to half its volume on a hot plate after which it was allowed to cool and then filtered. Stock solution was prepared of Aluminum, Cadmium, Lead, Iron, Copper and Manganese. Calibration solutions of the target metal ions were prepared from the standard stock by serial dilution. The digested water samples were analyzed for the presence of Aluminum, Cadmium, Lead, Iron, Copper and Manganese. Each sample was analyzed for Aluminum (Al), Cadmium $(\mathrm{Cd})$, Lead $(\mathrm{Pb})$, Iron $(\mathrm{Fe})$, Copper $(\mathrm{Cu})$ and manganese $(\mathrm{Mn})$ by using atomic absorption spectrophotometer (PYE Unicam SP9) technique, as described in (Bosnak and Groseer, 1996).

\section{Description the study area}

The study was conducted in Erbil city. The studied area (Erbil city) covers about 
$70 \mathrm{Km}^{2}$ between latitude $36^{\circ} 09^{-}$to $36^{\circ} 14^{-} \mathrm{N}$ and between longititude $43^{\circ} 58^{-}$to $44^{\circ} 03^{-} \mathrm{E}$ (Rzoska, 1980). Ten bottled waters were collected in various shops in the city on four replication during January to April-2010. The present study was carried out during a 4 month period on a total of 40 natural bottled water samples of 10 commercial brands produced in Iraq and Turkey that available in Erbil city to consume. The water type and source of each is represented in table (1).

\begin{tabular}{|c|c|c|}
\hline $\begin{array}{l}\text { Bottled water } \\
\text { brands }\end{array}$ & Water type & $\begin{array}{l}\text { Source of } \\
\text { water }\end{array}$ \\
\hline Ararat & $\begin{array}{c}\text { Natural } \\
\text { spring water }\end{array}$ & Erbil-Iraq \\
\hline Life & $\begin{array}{c}\text { Natural } \\
\text { spring water }\end{array}$ & Duhok-Iraq \\
\hline Cappinar & $\begin{array}{c}\text { Natural } \\
\text { spring water }\end{array}$ & $\begin{array}{l}\text { Istanbul- } \\
\text { Turkey }\end{array}$ \\
\hline Rawan & $\begin{array}{c}\text { Purified } \\
\text { drinking } \\
\text { water }\end{array}$ & Erbil -Iraq \\
\hline Avana & $\begin{array}{c}\text { purified } \\
\text { drinking } \\
\text { water }\end{array}$ & Erbil -Iraq \\
\hline Kani & $\begin{array}{c}\text { Natural } \\
\text { spring water }\end{array}$ & Erbil -Iraq \\
\hline Jin & $\begin{array}{c}\text { Natural } \\
\text { spring water }\end{array}$ & Duhok-Iraq \\
\hline Mina & $\begin{array}{c}\text { Natural } \\
\text { spring water }\end{array}$ & $\begin{array}{l}\text { Istanbul- } \\
\text { Turkey }\end{array}$ \\
\hline Azrak & $\begin{array}{c}\text { Natural } \\
\text { spring water }\end{array}$ & $\begin{array}{l}\text { Istanbul- } \\
\text { Turkey }\end{array}$ \\
\hline Rose & $\begin{array}{c}\text { Natural } \\
\text { spring water }\end{array}$ & \\
\hline
\end{tabular}

Table (1): The Bottled Water Type and Source of Each Brand

\section{Results and discussions:-}

Several elements considered in this study have been already determined in some bottled waters. (Fiket et al., 2007). Table 1, 2, 3, 4, 5 and 6 shows the level of the metals in the studied Bottled water samples given for Aluminum, Cadmium, Lead, Iron, Copper and Manganese. Statistically there are no significant differences between bottled water and dates for these studies.

The present investigation includes an Erbil city survey of trace element concentrations of bottled waters (10 brands) and thus is not limited to a specific geographical region. Therefore the data presented here provides an estimate of the range in concentrations of selected trace elements in bottled waters around the Erbil city.
In the following we focus on these elements for which only limited or no data are available or whose maximum concentrations in bottled waters was found to exceed guideline levels set by WHO.

For the protection of human health, guidelines for the presence of trace element in water have been set by different International Organizations such as United Stated of Environmental Protection Agency, World Health Organization, Environmental Protection Agency, European Union Commission (Marcovecchio et al., 2007). thus, trace element have maximum permissible level in water as specified by these organizations. Maximum contaminant level (MCL) is an enforceable standard set at a numerical value with an adequate margin of safety to ensure no adverse effect on human health. It is the highest level of a contaminant that is allowed in a water system. The six elements studied in this research namely: Aluminium, Cadmium , Lead, Iron, Copper and Manganese have Maximum Contaminant Levels of $0.2 \mathrm{mg} / \mathrm{L}$, $0.003 \mathrm{mg} / \mathrm{L}, 0.01 \mathrm{mg} / \mathrm{L}, 1 \mathrm{mg} / \mathrm{L}, 2 \mathrm{mg} / \mathrm{L}$ and $0.5 \mathrm{mg} / \mathrm{L}$ respectively (WHO, 2000).

Aluminium is the most abundant element found in the earth's crust (John De Zuane, 1990) and from the result obtained from its analysis; the minimum concentration of aluminium detected in the water samples for Bottled water was $0.000 \mathrm{mg} / \mathrm{L}$ with the maximum concentration being $0.007 \mathrm{mg} / \mathrm{L}$. None of the water samples contained Aluminium above the specified Maximum Contaminant Level $(0.2 \mathrm{mg} / \mathrm{L})$. However, Aluminium was detected in $50 \%$ of the water samples, and since toxicity is associated with continuous low level exposure, this can eventually lead to serious health effects as several epidemiological studies have provided evidence with respect to a possible link between Aluminium in drinking water and dementia as well as Aluminium exposure being an etiological factor in Alzheimer's disease.

In the analysis of the water samples collected for Cadmium, 3 of the collected bottled water samples did not contain detectable levels of Cadmium but of the 37 samples containing Cadmium, $30 \%$ of them were in concentrations above the Maximum Contaminant Level $(0.003 \mathrm{mg} / \mathrm{L})$ with the maximum concentration being $0.005 \mathrm{mg} / \mathrm{L}$. 
This is of concern because Cadmium has carcinogenic properties (Lauwerys, 1979). as well as a long biological half life (Orisakwe et al., 2006). leading to chronic effects as a result of accumulation in the liver and renal cortex. It can also cause kidney damage as well as produce acute health effects resulting from over exposure to high concentrations (Orisakwe et al., 2006).

The possible long term effects of chronic exposure to lead present in drinking water are subject to considerable public concern (Zietz et al., 2007). and in the analysis of the water samples collected for Lead, 28 of the bottled water were shown to contain Lead and of these, 16 of the bottled water representing $40 \%$ of the total contained Lead in levels above the Maximum Contaminant Level $(0.01 \mathrm{mg} / \mathrm{L})$ with the maximum concentration detected being $0.05 \mathrm{mg} / \mathrm{L}$. These results are of concern as lead has been recognised for centuries as a cumulative general metabolic poison (Adepoju-Bello and Alabi, 2005) (yes found in references) It is a neurotoxin and is responsible for the most common type of human metal toxicosis (Berman, 1980). Also, studies have linked lead exposures even at low levels with and increase in blood pressure (Zietz et al., 2007) as well as with reduced intelligence quotient in children (Needleman, 1993) and with attention disorders (Yule and Rutter, 1985). Iron is one of the most abundant metals in the earths crust. It is found in natural fresh water at level ranging from 0.5 to $50 \mathrm{mg} / \mathrm{L}$. Iron in drinking water dose not poses a health threat. Iron also produces an unpleasant taste in drinking water and may promote bacterial growth in pipes and service main (McNeely et al., 1979). It is content of hemoglobin, so it is very necessary for all living organism but in excess promote iron bacteria in water (Akhilesh Jinwal, 2009). It seem that values of Iron in the studied bottled water ranged between 0.20 to $0.45 \mathrm{mg} / \mathrm{L}$. Accordingly to WHO all studied Bottled water samples during this investigation were within desirable concentration and are on safe side for drinking purposes.

Copper is not known to be toxic to man at moderate level, but water becomes distasteful to drink at concentration of copper between 1 to $5 \mathrm{mg} / \mathrm{L}$ (CWQG, 1992).
The concentration of copper showed the highest values calculated in Rose and the lowest estimated in Avana bottled water which were $0.12 \mathrm{ppm}$ and $0.0 .02 \mathrm{ppm}$ respectively. According to limits prescribed by (WHO) it was found that all the samples collected from the sources were free from copper, the average value of copper in all water samples are much below the permissible limits. There was no health related risk due to the presence of copper in drinking water of the study areas. Copper values varied in the studied area, this may be related to variation in water characteristics such as $\mathrm{pH}$, hardness and copper availability in distribution system, corrosion of pipes or pipes fitting in the reticulation system (WHO, 2004). Contamination of drinking water with high level of copper may lead to chronic anemia (Acharya et al., 2008).

Manganese in the studied area varied between 0.00 to $0.085 \mathrm{mg} / \mathrm{L}$, this variation in concentration may be related to effect of soil, sediments and metamorphic and sedimentary rocks, which provide on appreciable natural sources of Mn through weathering. Iron and steel industry and acid mine drainage, in particular release a large portion of the manganese found in the environment (CWQG, 1992). Maximum acceptable level of $\mathrm{Mn}$ in drinking to $\mathrm{WHO}$ guideline is $0.4 \mathrm{mg} / \mathrm{L}$ (WHO, 2004), accordingly all studied wells considered safe for drinking purposes.

\section{Conclusion:-}

These results show high concentration of these trace elements and in some cases the levels were above WHO specified Maximum Contaminant level. In overall the Bottled water studied, concentration of Aluminium, Copper, Iron and Manganese were below the drinking water standards, but in Cadmium and Lead content of some samples surpassed the drinking water standards.

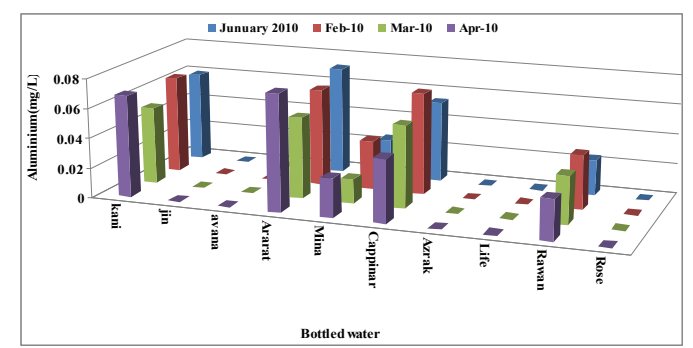

Figure (1): Aluminum (mg/L) values recorded in different Bottled water during the study period. 
Least significant difference (LSD) (0.01) for Date $=2.055833$

Least significant difference (LSD) (0.01) for Bottled water $=2.054499$

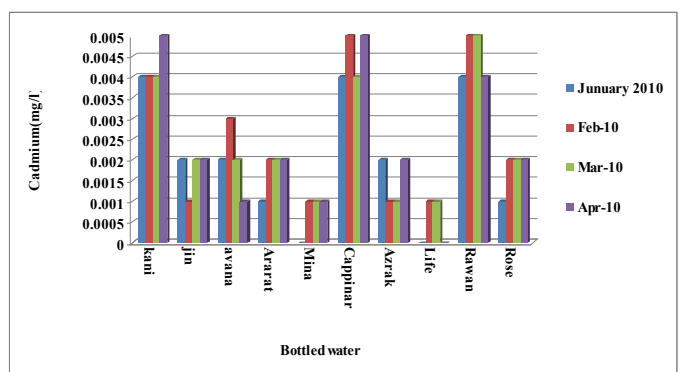

Figure (2): Cadmium $(\mathrm{mg} / \mathrm{L})$ values recorded in different Bottled water during the study period.

Least significant difference (LSD) (0.01) for Date $=2.052283$

Least significant difference (LSD) (0.01) for Bottled water $=2.052091$

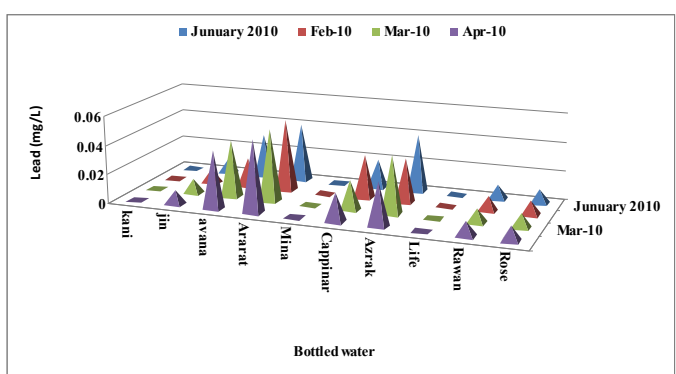

Figure (3): Lead $(\mathrm{mg} / \mathrm{L})$ values recorded in different Bottled water during the study period.

Least significant difference (LSD) (0.01) for Date $=2.055335$

Least significant difference (LSD) (0.01) for Bottled water $=2.053854$

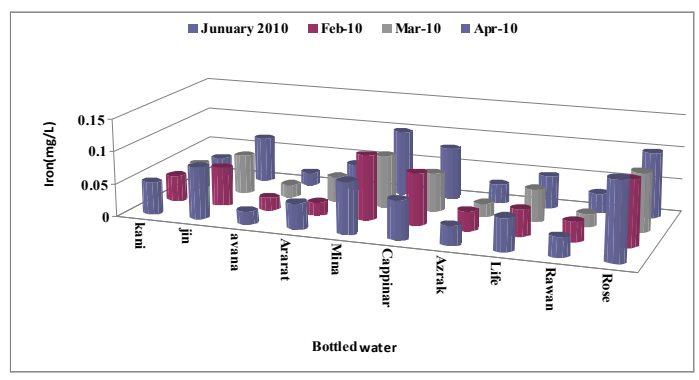

Figure (4): Iron $(\mathrm{mg} / \mathrm{L})$ values recorded in different Bottled water during the study period.

Least significant difference (LSD) (0.01) for Date $=2.096615$

Least significant difference (LSD) (0.01) for Bottled water $=2.077687$

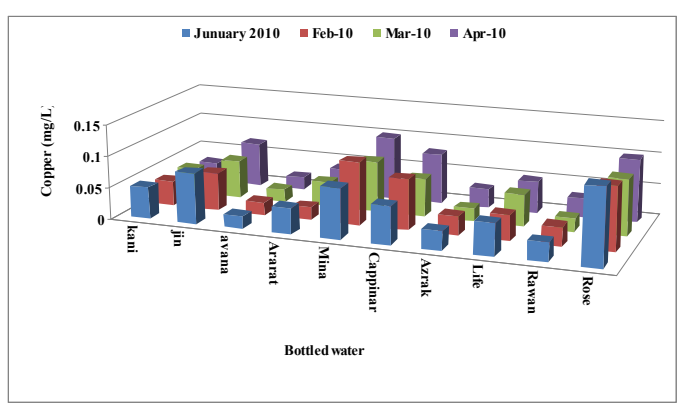

Figure (5): Copper $(\mathrm{mg} / \mathrm{L})$ values recorded in different Bottled water during the study period.

Least significant difference (LSD) (0.01) for Date $=2.058657$

Least significant difference (LSD) (0.01) for Bottled water $=2.055772$

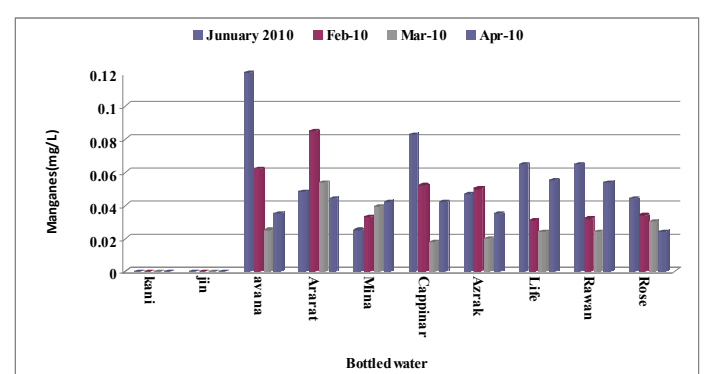

Figure (6): Manganese (mg/L) values recorded in different Bottled water during the study period.

Least significant difference (LSD) (0.05) for Date $=2.066093$

Least significant difference (LSD) (0.01) for Bottled water $=2.060065$

\section{References:-}

Jinwal, A., Dixit, S. and Malik S. (2009). Some Trace Elements Investigation in Ground Water of Bhopal \& Sehore District in Madhya Pradesh: India. J. Appl. Sci. Environ. Manage. December, 2009 Vol. 13 (4) $47-50$.

Acharya, G.D., Hathi, M.V., Patel, A.D. \& Parmar, K.C. (2008). Chemical properties of groundwater in Bailoda Taluka region, north Gujarat, India, viewed 23 June, 2010, <http://www.ejournals.in/PDF/V5N4/792-796.pdf $>$.

Adepoju-Bello, A.A. and Alabi, O.M. (2005). Heavy metals: A review. The Nig. J. Pharm., 37: 41-45.

Bakare-Odunola, M.T. (2005). Determination of some metallic impurities present in soft drinks marketed in Nigeria. The Nig. J. Pharm., 4(1): 51-54.

Berman, E. (1980). Toxic Metals and Their Analysis. Philadelphia, PA: Hayden and Sons.

Bosnak, C.P. and Groseer, Z.A. (1996). The analysis of drinking water and bottled 
water by flame atomic absorption and GFAA.Atomic spectroscopy.17:218221.

Canadian Council of Resource and Environment Ministers. Canadian Water Quality Guideline. Ottawa Ontario. Task Force on Water Quality Guideline. (1992). Water Quality Branch, Inland Water Directorate. 88pp.

Dorothy, S. and Nicholas, D. (2005). Technology of Bottled Water. $2^{\text {nd }}$ Edition.By Blackwell Publishing Ltd. 262pp.

Fiket, Ž. Roje, V. Mikac, N. Kniewald, G. (2007). Determination of arsenic and other trace elements in bottled waters by high resolution inductively coupled plasma mass spectrometry. Croat Chem Acta; 80:91-100.

John, D., Zuane, P.E. (1990). Chemical Parameters-Inorganic. In: Quality Standards and Constraints. New-York: Von Nostrand and Reinhold, pp: 47-151.

Lauwerys, R.R. (1979). Health Effects of Cadmium. In: Trace Metal: Exposure and Health Effects. E. DiFerrante, (Ed.). Oxford, England: Pergamon Press, pp: 43-64.

Marcovecchio, J.E., Botte, S.E. and Freije, R.H. (2007). Heavy Metals, Major Metals, Trace Elements. In: Handbook of Water Analysis. L.M. Nollet, (Ed.). $2^{\text {nd }}$ Edn. London: CRC Press, pp: 275-311.

McMurry, J. and Fay, R.C. (2004). Hydrogen, Oxygen and Water. In: McMurry Fay Chemistry. K.P. Hamann, (Ed.). 4th Edn. New Jersey: Pearson Education, pp: 575-599.

McNeely, R.N., Neimanis, V.P. and Dwyer, L. (1979). Water Quality Source-Book. A Guide to Water Quality Parameters. Ottawa, Canada. Environment Canada. Inland Water Directorate. Water Quality Branch. 88pp .

Mendie, U. (2005). The Nature of Water. In: The Theory and Practice of Clean Water Production for Domestic and Industrial Use. Lagos: Lacto-Medals Publishers, pp: $1-21$.

Michael, K. and William S. (2009). Trace and ultra trace metals in bottled waters: Survey of sources worldwide and comparison with refillable metal bottles. Sciences of the total Environment 407:1089-1096.

Needleman, H.L. (1993). The current status of childhood low-level lead toxicity. Neurotoxicology, 14: 161-166.

Orisakwe, O.E., Igwilo, I.O. Afonne, O.J. Maduabuchi, J.U. Obi, E. and Nduka, J.C. (2006). Heavy metal hazards of sachet water in Nigeria. Arch. Environ. Occup. Health, 61(5): 209-213.

Rzoska, J. (1980). Euphrates and Tigris, Mesopotamian Ecology and Destiny. Vol: 38. Mongr. Biol.W. Junk. The Hague-Boston. London.122p.

Shotyk, W., Krachler, M., Chen B. (2006). Contamination of Canadian and European bottled waters with antimony from PET containers. J Environ Monit; 8:288-92.

Vanloon, G.W. and Duffy, S.J. (2005). The Hydrosphere. In: Environmental Chemistry: A Global Perspective. 2nd Edn. New York: Oxford University Press, pp: 197-211.

Versari, A., Parpinello, G.P., Galassi, S. (2002). Chemometric survey of Italian bottled mineral waters by means of their labeled physico-chemical and chemical composition. J Food Compos Anal;15:251-64.

Vodela, J.K., Renden, J.A. Lenz, S.D. Mchel, W.H. Henney, and Kemppainen, B.W. (1997). Drinking water contaminants. Poult. Sci., 76: 1474-1492.

Warburton, D.W. and Austin, J.W. (2000). Bottled water, in the Microbiological Safety and Quality of Food(eds, B.M. Lund, T.C. Baird Parker and G.W. Gould). Volum1 An Aspen Publication.

WHO, (2000). Hazardous Chemicals in Human and Environmental Health: A Resource Book for School, College and University Students. World Health Organisation, Geneva.

WHO, (2007). Water for Pharmaceutical Use. In: Quality Assurance of Pharmaceuticals: A Compendium of Guidelines and Related Materials. 2nd Updated Edn. World Health Organisation, Geneva, 2: 170-187.

WHO, (2004). Guideline for Drinking-Water Quality. $\quad 3^{\text {rd }}$ Edition. Volume 1. Recommendation. Geneva. 515pp.

Yule, W. and Rutter, M. (1985). Effect on Children's Behavior and Cognitive Performance: A Critical Review. In: Dietary and Environmental Lead $(\mathrm{Pb})$ : Human Health Effects. R. Mahaffey, (Ed.). New York: Elsevier, pp: 211-251.

Zietz, B., Dassel, de Vergara, J., Kevekordes S., Dunkelberg, H. (2001). Lead contamination in tap water of households with children in Lower Saxony, Germany. Sci Total Environ; 275:19-26.

Zietz, B.P., Dieter, H.H., Lakomek, M., Schneider, H., Keßler-Gaedtke, B., Dunkelberg, H., Epidemiological 
investigation on chronic copper toxicity to children exposed via the public drinking water supply. Sci Total Environ (2003) 302:127-44.
Zietz, B.P., Lap, J. and Suchenwirth, R. (2007). Assessment and management of tap water Lead contamination in Lower Saxon, Germany. Int. J. Environ. Health Res., 17(6): 407-418.

\section{تقدير محتوى المعادن الضئيلة للمياه المعلبة المتوفرة في مدينة اربيل-العراق}

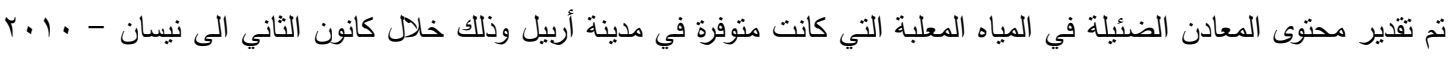
والتي تم جمعها من محلات مختلفة في المدينة. تم تحليل عشرة نماذج للمياه المعلبة باستخدام جهاز امتصاص الطيف الذري للمعادن

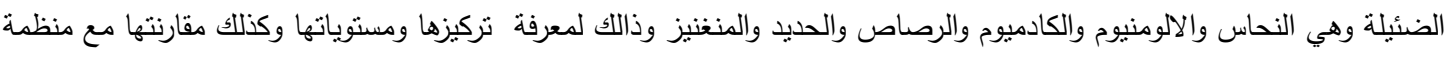

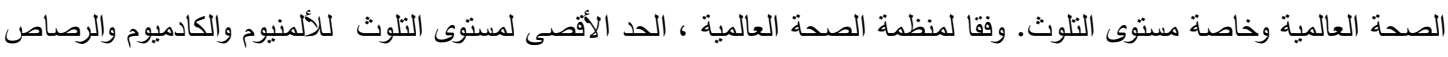

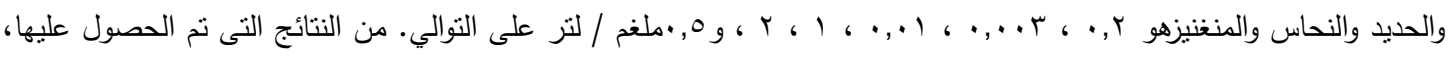

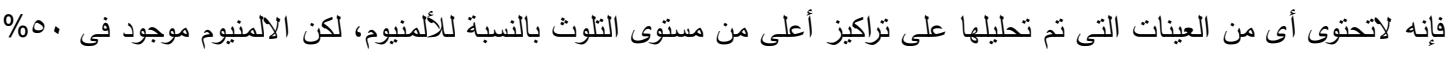

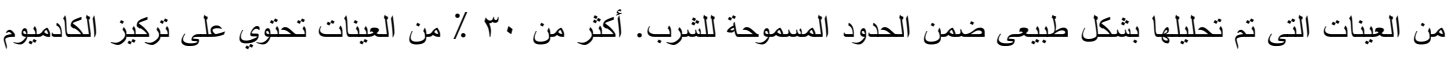

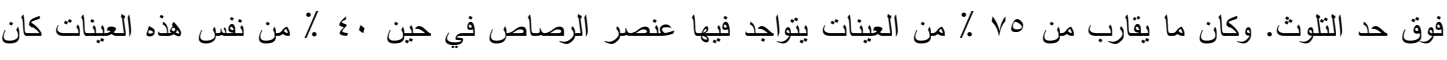
تركيز الرصاص فيها فوق حد التلوث. أظهرت النتائج أن تركيز الحديد ، النحاس والمنغنيز في جميع العينات هو اقل من حد التلوث وفقا لمنظمة الصحة العالمية. التحاليل التي اجريت بواسطة جهاز مطياف الذري للمعادن، اظهرت ان نركيز معظم المعادن الضئيلة

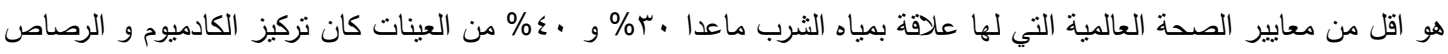
اعلى من مستوى التلوث على التوالي اي انها غير صالحة للشرب من ناحية نركيز هذه المعادن. 